\title{
Self-deception in The Sense of an Ending
}

\author{
Yueqing Yuan \\ Shanghai International Studies University, Shanghai, China
}

\begin{abstract}
Julian Barnes's The Sense of an Ending conveys his humanistic concern about individuals' psychological dilemmas. This essay focuses on the self-deception of the internal narrator Tony. It analyses how his defence mechanisms assist his self-deception and how his narrative discourses reflect the instability of his self-deception. Tony is an example of those who indulge in self-deception and fail to take on due duty. Individuals tend to struggle between deceiving and facing themselves. Those who know themselves better are better prepared for shouldering responsibility and addressing problems.
\end{abstract}

\section{Index Terms - Julian Barnes, The Sense of an Ending, self-deception}

\section{INTRODUCTION}

The Sense of an Ending by Julian Barnes (1946- ) is about "a man coming to terms with the mutable past" ("The Man Booker Prize”, 2011). There are four events that are of particular importance: Tony's visit to Veronica's family, his breakup with her, her subsequent involvement with Adrian, and Adrian's suicide. Tony is the protagonist and narrator of the story. He believes that he has "an instinct for self-preservation" (Barnes, 2011, p. 42, p. 64, p. 131). He claims that he is "peaceable" (Barnes, 2011, p. 35, p. 42) and that he has achieved "a state of peaceableness, even peacefulness" in his life (Barnes, 2011, p. 68). But his self-image is once challenged by Veronica:

'You're quite cowardly, aren't you, Tony?'

'I think it's more that I'm...peaceable.'

'Well, I wouldn't want to disturb your self-image.' (Barnes, 2011, p. 35)

Tony's inclination for self-deception goes with his instinct for self-preservation. He is too cowardly to face himself and can only deceive himself that he is a peaceable person and lives a peaceable life. He is forced to disturb his self-image in his sixties, when he sees the photocopy of the letter he writes back to Adrian in his twenties. He finally faces up to the negative side of his self-identity as a "chippy, jealous and malign" person (Barnes, 2011, p. 97). Present studies of the novel mainly focus on narrative skills such as unreliable narration and thematic concerns about history, memory, ethics, or self-identity. Some of them give insights into Tony's subtle and contradictory psychology. This essay focuses on Tony's self-deception and aims to figure out Barnes's humanistic concern about individuals' psychological dilemmas.

\section{TONY' S SELF-DECEPTION ASSISTED By DEFENCE MECHANISMS}

Individuals form their identities based on what they do, think and feel. When they conduct or encounter destructive behaviours or have psychologically threatening thoughts or feelings, those with a propensity for self-deception tend to evade, repress or deny them, so as to defend themselves (Paulus, 1991; Tyson, 2006). Internal narrators tend to deceive themselves when they try to maintain a positive self-identity in the process of self-construction under no interpersonal pressure (Zhu et al, 2016; Fan et al, 2017). Defence mechanisms refer to the ego's struggles against unendurable affects resulting from destructive behaviours, threatening thoughts or unpleasant feelings (Freud, 1966; Tyson, 2006). In The Sense of an Ending, Tony's defences help him to deceive himself, to maintain a relatively positive self-image, and so as to live in a state of peaceableness.

Tony projects his feelings and problems onto Veronica and Adrian, and then condemns them. Tony does not take his relationship with Veronica seriously, merely desiring to "[have] a nice time" and "enjoy the day and all that" (Barnes, 2011, p. 34). On the contrary, Veronica is prudent and serious about the progress of their intimacy. Tony does not perceive her seriousness but projects his unserious and irresponsible attitude onto her. He mistakenly thinks that Veronica holds the same opinion as his: “...the fact that we weren't having sex exonerated me from thinking about the relationship other than as a close complicity with a woman who, as her part of the bargain, wasn't going to ask the man where the relationship was heading" (Barnes, 2011, p. 25-26). So when Veronica asks him where their relationship is heading and whether they are suited, they cannot reach a consensus. Their argument makes Tony feel that he can enjoy the day no longer, so he begins to think about leaving her. For Tony, it is Veronica who breaks their "complicity".

Besides, Tony also projects his meanness and maliciousness onto Adrian and Veronica. Partly out of Veronica's suggestion, Adrian writes a letter to ask Tony's permission to go out with Veronica. Adrian says that if Tony cannot understand or accept it, he "[owes] it to [their] friendship to reconsider his actions and decisions" (Barnes, 2011, p. 41). The letter manifests Veronica's generosity and their courtesy. If Tony can be kind and friendly, he can relieve the tension and hostility he has created between he and Veronica, and remain their friend. But Tony projects his meanness and 
maliciousness onto them. So he cannot perceive a tinge of goodwill the letter conveys and only has malicious interpretations:

I enjoyed the bit about his moral scruples.... I also liked the hypocrisy of a letter whose point was not just to tell me something I might not have found out anyway (or not for quite a while), but to let me know how she, Veronica, had traded up: to my cleverest friend, and, what's more, a Cambridge chap like Brother Jack. Also, to warn me that she would be hanging around if I planned on seeing Adrian - which had the desired effect of making me plan not to see Adrian. (Barnes, 2011, p. 41) (emphasis added)

Through projection, Tony self-deceptively feels that Adrian and Veronica are hypocrites and betrayers, while he is a victim. Thus, he has reason to condemn and punish them.

Tony has selective memory regarding his entanglement with Veronica and Adrian. He distorts unpleasant memory to reduce its negative impacts or forgets painful events entirely (Tyson, 2006). His selective memory is presented by the disparities of details between what he has remembered and what he newly recollects, and between his memory and the fact.

Tony's memory is selective regarding his relationship with Veronica. He has remembered that Veronica refuses to dance with him and that she despises his record collections. But after he reconnects with her in his sixties, he recalls that she has invited him to play his pop records and to dance; he even recollects a particular scene of her dancing. In addition, regarding the Severn Bore, Tony has remembered that he stays on the bank by himself, but old Tony recalls that Veronica has been alongside him and he thinks that "[his] brain must have erased it from the record" (Barnes, 2011, p. 119). Regarding his visit to Veronica's family, his memory is also defective. He has remembered that her father perplexes him by talking about the St. Michael's church and Café Royal, but when old Tony googles them, he discovers that there have never been these buildings. Tony also remembers that on the second evening, Veronica walks him upstairs, but old Tony recalls more details: while coming upstairs with him, she says she is going to walk him to his room and takes his hand in front of the family. Besides, Tony remembers that Jack winks at him superciliously and contemptuously, but old Tony is surprised that when he turns to Jack for help, he is polite and helpful. Before Tony reconnects with Veronica, his memory has been selective, in which Veronica is cold and arrogant, and her father and brother are contemptuous. His selective memory helps him to apportion blame for his breakup with Veronica.

Tony's memory is vague and contradictory regarding the key events related to his breaking with Veronica and Adrian. Firstly, about his breakup with Veronica, he remembers that "After we broke up, she slept with me" (Barnes, 2011, p. 36). But in his monologue he says that "After we broke up, she slept with me' flips easily into 'After she slept with me, I broke up with her"” (Barnes, 2011, p. 44). Secondly, about Adrian's letter, he remembers that: "Adrian said he was writing to ask my permission to go out with Veronica", but then he modifies his narration: "Actually ... what [Adrian] said was that he and Veronica were already going out together ..." (Barnes, 2011, p. 41). His memory and narration are confusing and suspicious. Thirdly and most importantly, regarding Tony's reply to Adrian, his memory is far less offensive than the fact. Tony remembers that he sends back the nearest postcard to hand, in which he writes silly but unambiguous words to pretend that he does not mind in the slightest. At last, he replies to them with a letter:

... at last, I replied to it properly, I didn't use any of that silly 'epistle' language. ... I told him pretty much what I thought of their joint moral scruples. I also advised him to be prudent, because in my opinion Veronica had suffered damage a long way back. Then I wished him good luck.... (Barnes, 2011, p. 43) (emphasis added)

His memory of Adrian's letter and his reply implies that he has occupied the moral high ground. But the photocopy of the original letter reveals that it is an ugly epistle composed of malicious calumniation, curses, and abetment (Barnes, 2011, p. 95-97). Old Tony is stunned by "the ugly vitriol dripping from every line" and "the destructive malice" which does not support his self-image "as a decent fellow, more sinned against than sinning" (Holmes, 2015, p. 35). The malice of his letter eventually reminds him of the postcard "of the Clifton Suspension Bridge, from which a number of people every year jump to their deaths" (Barnes, 2011, p. 98). Tony "forgets" the details of his reply together with the dark side of his self-image. But as old Tony sees the photocopy of his letter, he is forced to face it.

In addition, Tony avoids people and things that might remind him of Veronica, Adrian and what he has done to them, because they are "liable to make [him] anxious by stirring up some unconscious- i.e., repressed - experience or emotion" (Tyson, 2006, p. 15). After replying to Adrian, Tony burns Adrian's letter and decides that Adrian and Veronica are "out of [his] life forever" (Barnes, 2011, p. 43). After informed of Adrian's suicide, he does not contact Adrian's family or Veronica. He swears to repeat the commemoration of Adrian annually with Colin and Alex, but gradually he loses touch with them. He keeps no letters related to Veronica, and only a single photograph, which he has not looked at in ages. In addition to avoidance, Tony also has the inclination for denial, "believing that the problem does not exist or the unpleasant incident never happened" (Tyson, 2006, p. 15). Tony tries to expunge Veronica from his life story:

I did a slightly odd thing when I first met Margaret. I wrote Veronica out of my life story. I pretended that Annie had been my first proper girlfriend. ... The odder part was that it was easy to give this version of my history because that's what I'd been telling myself anyway. I viewed my time with Veronica as a failure - her contempt, my humiliation - and expunged it from the record. (Barnes, 2011, p. 69) (emphasis added)

In order to live in a state of peaceableness, Tony banishes himself from people and things related to Veronica and Adrian. 
Tony's self-deception goes with his defences. He cannot face his true self or take responsibility for his behaviours, so he struggles to deceive himself so as to reach a state of peaceableness. He projects his weaknesses and problems onto Veronica and Adrian, so he has reason to condemn them and break with them. His memory becomes selective and self-serving. He avoids people and things related to them. He even tries to deceive himself that Veronica has never been his girlfriend. His breaking with Veronica and Adrian manifests his core issue that he always tends to apportion blame and evade his own responsibility. But he is too cowardly to face and examine himself, so he never addresses his core issue effectively. It stays with him throughout life and determines his behaviours in destructive ways of which he is probably unaware (Tyson, 2006, p. 17). Thus, he only lives a life of mediocrity, without a happy family or a successful career, and indulges himself in the illusion of peaceableness.

\section{INSTABILITY OF TONY's SELF-DECEPTION MANIFESTED IN NARRATIVE DiSCOURSES}

Internal narrators can tell "a mixture of knowledge, lies, self-deception, delusion and plain error" (Currie, 2010, p. 67). A self-deceptive narrator does not explicitly express the truth but provide a rendered story "as internally consistent and natural as possible, and as closely confirming as possible to the evident facts" (Fingarette, 1969, p. 49). But "self-deception is an unstable mental phenomenon"; its instability stems from the desire to conceal and to reveal the truth at the same time (Marcus, 2016, p. 129). Thus, self-deceptive narrators often tell their stories in an ambiguous and contradictory way. They set up a narrative identity, which acknowledges past actions, but disclaims them to the past self and commits them to the present self (Vaughan, 2007; Zhu et al, 2016). The process of narrating can lead to changes in self-knowledge and self-image.

In The Sense of an Ending, even though Tony reveals his original letter to Adrian and the truth behind Adrian's death, it remains difficult to restore the causes and effects, since as a character-narrator he can only give a limited perspective. But his narrative discourse gives a clear manifestation of his thoughts and feelings. Based on his own memory, the former part of his narration can hardly be a reliable account of what has happened, but it is a true reflection of his understanding and feelings about himself, Adrian, Veronica, and her family. The vagueness and contradictoriness of his discourse reflect his struggle between deceiving and facing himself. The instability of his self-deception is manifested in his narrative discourse through certain verbal patterns and narrative characteristics.

Tony tends to use one verbal pattern to state that his narration is true to his memory rather than actual facts. He cannot assure that what he remembers equals what has happened. For example:

(1) If I can't be sure of the actual events any more, I can at least be true to the impressions those facts left. (Barnes, 2011, p. 4)

(2) Was this their exact exchange? Almost certainly not. Still, it is my best memory of their exchange. (Barnes, 2011, p. 18-19)

(3) Actually, to be true to my own memory, as far as that's ever possible (and I didn't keep this letter either)... (Barnes, 2011, p. 40)

(4) Again, I must stress that this is my reading now of what happened then. Or rather, my memory now of my reading then of what was happening at the time. (Barnes, 2011, p. 41)

This pattern indicates that Tony tries to assure the reliability and accuracy of his narration, more to himself than to the narratee. It also implies that Tony cannot remember past events in an unbiased way. His memory is a mixture of facts and his interpretations. This pattern manifests his conflicting desire to conceal and reveal the truth at the same time. It is a clue to his self-deception.

Another verbal pattern, which is more frequently used, is that Tony doubts or even negates the reliability of his memory. Such a pattern is used especially when it is likely that Tony has misunderstood others, has misjudged a situation, or tries to projects his own problems or emotions onto others. For example, when he narrates the weekend he spends with Veronica's family, who are posher and who he regards as supercilious, he questions whether or not he has indeed been despised by them:

(1) ...this is my principal factual memory. The rest consists of impressions and half-memories which may therefore be self-serving... (Barnes, 2011, p. 27-28)

(2) Perhaps this was mere paranoia. (Barnes, 2011, p. 29)

(3) Or was this mere paranoia on my part? (Barnes, 2011, p. 73)

In addition, when he recalls his argument with Veronica about whether their relationship is heading, he also doubts his memory:

Or have I just remembered it this way to make it seem so, and to apportion blame? If asked in a court of law what happened and what was said, I could only attest to words 'heading', 'stagnating' and 'peaceable'. I'd never thought of myself as peaceable - or its opposite - until then. I would also swear to the truth of the biscuit tin; it was burgundy red, with the Queen's smiling profile on it. (Barnes, 2011, p. 35)

Besides, after old Tony reconnects with Veronica, he recalls that Veronica has seen the Severn Bore with him, which is contradictory to his previous memory that he sees it by himself. But he immediately doubts his memory and imagines that he is questioned in a court of law:

At least, that's how I remember it now. Though if you were to put me in a court of law, I doubt I'd stand up to cross-examination very well. 'And yet you claim this memory was suppressed for forty years?' 'Yes.' 'And only 
surfaced just recently?' 'Yes.' 'Are you able to account for why it surfaced?' 'Not really.' 'Then let me put it to you, Mr Webster, that this supposed incident is an entire figment of your imagination, constructed to justify some romantic attachment which you appear to have been nurturing towards my client, a presumption which, the court should know, my client finds utterly repugnant.' ... 'Oh please, Mr Webster, spare us your sentimental lucubrations. This is a court of law, which deals with fact. What exactly are the facts in the case?'

I could only reply that I think - I theorize - that something - something else - happens to the memory over time. ... (Barnes, 2011, p. 119-120)

Tony's doubt and negation of his memory demonstrate his unconscious struggle between the compulsion to confess and the tendency to disguise. But his propensity for self-deception seems to be strong than his desire to disturb his self-image. After he is informed of Veronica's mother's bequest, he is puzzled and attempts to search in his memory for "any moment, incident or remark which might have seemed worthy of acknowledgement or reward"; but it is in vain because "[his] memory has increasingly become a mechanism which reiterates apparently truthful data with little variation" (p. 60). "History is that certainty produced at the point where the imperfections of memory meet the inadequacies of documentation" (Barnes, 2011, p. 17). The quick passage of time, the lack of documentation and the strong defence mechanisms prevent Tony from going out of the mist of his memory. But he does not believe his memory entirely. The verbal pattern that he doubts or negates the reliability of his memory also implies the instability of his self-deception.

Regarding narrative characteristics, firstly, the narration is fragmental. The fragmentation of narration serves to conceal something. The narration of the events tends to be incomplete and vague. There are always something unknown or unstated. Some events are not witnessed by Tony, some are "forgotten", and some are distorted. For instance, at the beginning of the narration, Tony lists six fragments that he remembers in no particular order, and the last one is "bathwater long gone cold behind a locked door" (Barnes, 2011, p. 3). This scene is about Adrian's suicide which is not witnessed by Tony. But "what you end up remembering isn't always the same as what you have witnessed" (Barnes, 2011 , p. 3). Tony only hears of how he commits suicide, and he does not know why. But he has imagined the scene since it is an important event in his life. Tony's memory and narration of the key events related to his traumatic entanglement with Veronica and Adrian tend to be self-serving. The narration of those events is fragmental, incomplete, and subjective, so it is impossible to grasp the actual fact. The fragmentation of narration helps to conceal his destructive behaviours, to deceive Tony himself and to confuse the reader. But it is not difficult for sensitive readers to hear "those words as expressive of calculation, or self-deception - or something else not wholly virtuous" (Currie, 2010, p. 62). Tony's self-deception and his true self-image can be perceived through the details of his narration.

Secondly, the narration is disjointed. The narration of the past and the narration of the present are interwoven together This pattern is more obvious in the latter part of the narration. For example, the narration of old Tony's quest for Veronica's mother's bequest is interwoven by the narration of young Tony's dates with Veronica. It breaks the chronological order and creates distances between the narrator's multiple recollections. In addition, the narration of events is constantly interrupted by the narrator's monologue. It is difficult to tell whether the monologue is "[his] reading now of what happened then" or it is "[his] memory of [his] reading then of what was happening at the time" (Barnes, 2011, p. 41). The disjointed narration produces a sense of hesitation and procrastination. The narration of the past and the inserted monologue mainly serve to conceal the truth, while the narration of the present and the re-narration of the past serve to reveal the hidden part which the narrator finds difficult to face up to. The disjointed structure also manifests the instability of Tony's self-deception.

Lastly, the narration is divided into two parts. As the narrator, Tony in his sixties has known the sequence of events and the causes and effects. But the story is not narrated directly according to what he has figured out. Instead, the former part of the narration tells about the past based on his previous memory, and the latter part tells about how he quests for Veronica's mother's bequest, gains the photocopy of his letter, gets to know the truth behind Adrian's death and modifies his memory. The latter part includes an implicit, more accurate retelling of the past triggered by Tony's modification of memory and his knowing of the unknown fact. On the whole, the former part of narration serves to conceal, while the latter part to reveal. The first part is self-serving to Tony. When telling his own life story, "[he] adjust[s], embellish[es], and make[s] sly cuts", so it is a story "[t]old to others, but- mainly - to [himself]" (Barnes, 2011, p. 95). In the second part, Tony recalls something that is contradictory to what he has remembered. But most importantly, the reveal of the photocopy of his original letter proves that his self-image as a peaceable person is fake and deceptive. Even when Tony sees the photocopy, he is still struggling: "I could scarcely deny its authorship or its ugliness. All I could plead was that I had been its author then, but was not its author now. Indeed, I didn't recognise that part of myself from which the letter came. But perhaps this was simply further self-deception” (Barnes, 2011, p. 91). Worse still, he finds that part of his evil curses have come true: Adrian's involvement with Veronica's mother, their abnormal child, Adrian's suicide and Veronica's suffering. Thus, Tony cannot help feeling ashamed and guilty and can hardly absolve himself from blame. The second part reveals the negative side of Tony's self-image and also reveals the tragedies of Adrian and Veronica, which have something to do with Tony. The narration divided into two parts also presents Tony's struggle between concealing and revealing his true self.

The verbal pattern that Tony uses to assure the reliability of his narration, which is true to his memory rather than actual facts, and the one that he uses to doubts or even negates the reliability of his memory indicate Tony's conflicting 
desire to conceal and reveal at the same time. Moreover, the narrative characteristics that the narration is fragmental, disjointed, and divided into two parts, also manifest the instability of Tony's self-deception. Tony has been a self-deceiver. But he is also a confessor. After he confronts the reality, he chooses to reveal the hidden, negative part of his self-image and confesses his evil intentions and destructive behaviours. His narration presents vividly how he has deceived himself and how he is forced to face it. The process of narrating manifests his struggle but it eventually leads to revelation. By narrating, Tony confesses his faults, reconstructs his self-image, and in the meantime admonishes the reader.

\section{CONCLUSION}

Tony is not entirely unaware of his weaknesses and evil intentions. But he has been too cowardly to face and change them. When confronted with problems, he tends to apportion blame in order to evade his guilt and fake a state of peaceableness. Eventually in his sixties, he faces up to his cowardice, selfishness, maliciousness, and irresponsibility, but "too much time has passed, too much damage has been done, for amends to be made" (Barnes, 2011, p. 99). He has lost the chance to be a better man and to shouldering his due responsibility.

Self-deception is common. It can be perceived everywhere in everyone (Warren, 2014). The only distinction lies in to what extent individuals deceive themselves. Self-deception helps individuals defend against negative affects resulting from destructive behaviours, threatening thoughts or unpleasant feelings, but it also prevent individuals to undertake duties. Those who can face and know themselves well are better equipped for the due responsibility of life than those who indulge in self-deception (Jopling, 2000). Facing and knowing oneself requires courage and honesty. When individuals know themselves better, they are better prepared for shouldering responsibility and addressing problems.

\section{REFERENCES}

[1] Barnes, J. (2011). The Sense of an Ending. London: Jonathan cape.

[2] Currie, G. (2010). Narratives and Narrators: A Philosophy of Stories. Oxford: Oxford University Press.

[3] Fan, W., Yang B., Liu, J., \& Fu, X. (2017). Self-Deception: For Adjusting Individual Psychological State. Advances in Psychological Science, 25(8), 1349-1359.

[4] Fingarette, H. (1969). Self-Deception. London: Routledge \& Kegan Paul.

[5] Freud, A. (1966). The Ego and The Mechanisms of Defence (revised ed.). London: Karnac Books,

[6] Holmes, F. M. (2015). Divided Narratives, Unreliable Narrators, and The Sense of an Ending: Julian Barnes, Frank Kermode, and Ford Madox Ford. Papers on Language \& Literature, 51(1), 27-50.

[7] Jopling, D. A. (2000). Self-Knowledge and the Self. New York, NY: Routledge,.

[8] Marcus, A. (2006). Kazuo Ishiguro's The Remains of the Day: The Discourse of Self-Deception. Journal of Literature and the History of Ideas, 4(1), 129-150.

[9] Paulus, D. L. (1991). Measurement and Control of Response Bias. In J. P. Robinson, P. R. Shaver \& L. S. Wrightsman (Ed.), Measures of Personality and Social Psychological Attitudes (pp. 17-59). San Diego, CA: Academic Press.

[10] The Man Booker Prize 2011. http://themanbookerprize.com/fiction/2011 (accessed 6/9/2018).

[11] Tyson, L. (2006). Critical Theory Today: A User-Friendly Guide (2nd ed.). New York, NY: Routledge.

[12] Vaughan, B. (2007). The Internal Narrative of Desistance. British Journal of Criminology, 47(3), 390-404.

[13] Warren, C. (2014, May 3). Honest Liars - the Psychology of Self-Deception: Cortney Warren at TEDxUNLV. Retrieved from https://www.youtube.com/watch?v=YpEeSa6zBTE (accessed 6/9/2018).

[14] Zhu, Y., Xi, S., \& Wu Y. (2016). Self-Deception in Autobiographical Narrative: Individuals' Self-Identity Strategy. Advances in Psychological Science, 24(12), 1917-1925.

Yueqing Yuan was born in Dongguan, Guangdong, China in 1994. She is currently a postgraduate student in the School of English Studies, Shanghai International Studies University. Her research interests include contemporary British and American literature. 